\title{
Rebuilding the Angolan body politic: Global and local projections of identity and protest in $O$ Herói/The Hero (Zézé Gamboa, 2004)
}

Mark Sabine University of Nottingham

\begin{abstract}
This article uses a reading of Zézé Gamboa's award-winning 2004 feature as a basis for an exploration of post-conflict Angolan screen culture and of its impact both at home and internationally. It considers how $O$ Herói's depiction of a war-torn nation, and of the impediments to its reconstruction, negotiates between a socially-engaged film-making practice, informed by local tradition and the tenets of 'Third Cinema', and the demands of a globalised cinema market. The film achieves this compromise by deploying allegorical and symbolic tropes, familiar from the literature, cinema, and political discourse of the era of Angolan liberation (notably, the concept of a socialist 'new man'), to complicate a superficially optimistic story of post-conflict rehabilitation, and to insinuate a critique of the authoritarian practices and neo-liberal policies of the MPLA government. Further to this, the article identifies strategies through which the film advertises the gulf between its fiction of individual triumph over adversity and, on the other hand, the grimmer reality of Angola's post-conflict malaise. Finally, it considers how the film's construction of an encrypted allegory also prompts the question of whether or not film production that depends upon the funding and agendas of international capital and neo-colonial powers can ever foster the resurgence of a genuinely 'popular' and progressive culture in post-conflict Angola.
\end{abstract}

\section{Keywords \\ Angola \\ post-conflict culture \\ African cinema \\ national identity \\ human rights}

Amid the fragile optimism generated by the Luena Peace Memorandum of 4 April 2002, the year 2004 appeared to many observers to be an annus mirabilis for film-making in Angola. The decades of armed conflict that devastated the country had also gradually snuffed out its short but distinguished film-making tradition, and indeed made film viewing inaccessible to most of the population. ${ }^{1}$ The release in that year of three homegrown feature films, O Comboio da Canhoca/Canhoca Train (Orlando Fortunato), Na Cidade Vazia/Hollow City (Maria João Ganga), and The Hero led to talk of a renaissance in Angolan cinema, sponsored by a reactivated national Film and Multimedia Institute. In spite of continuing international acclaim for the latter two films in particular, such talk now looks to have been somewhat premature. Continuing peace and a spectacular 
economic boom have expanded opportunities for cultural expression even in what remains a less than free and pluralist democratic Angola. ${ }^{2}$ However, it will take longer to address the dearth of funding for film productions, and the gaps in local film-making infrastructure and expertise, for which each of the three 2004 features took over a decade to produce, and was reliant on overseas funding. ${ }^{3}$ While the gradual emergence of a viable local film industry remains a possibility, though, the three films offer inspiring examples of how Angolan film-makers might address the concerns and desires of local audiences even while finding themselves constrained by the country's post-conflict circumstances, and obliged to attract funding and audiences from distant centres of power within an ever more globalized film and media industry. In relation to this issue, The Hero in particular is remarkable for the means by which it balances the aim of commenting on social and political realities in post-conflict Angola with the necessities of negotiating restrictions on freedom of expression at home, and of engaging an international audience that is largely unfamiliar with Angolan cultural and historical specificities. At first glance, The Hero presents a simple, heart-warming tale of post-war survival and rehabilitation, which are endangered by anti-social attitudes and practices, but that are ultimately achieved through selflessness and solidarity. Closer inspection, however, reveals its powerful critique not just of Angolan society but also and particularly of the nation's post-conflict political order. In the globalized context that contemporary Angolan film production must address in order to be financially viable, what is particularly remarkable is that The Hero's critique entails the reaffirmation of an expressly national culture and ethos. The film's appeal for the revival of 'a solidariedade angolana' (Angolan solidarity) implies a return to the socialist agenda of the independence era, which the leadership of the MPLA (Movimento Popular de Libertação de Angola), in government since independence in 1975, had long since consigned to the lumber room. ${ }^{4}$ The film conveys this message through a diegesis and a visual language wherein time-honoured symbols of 'national' values of community and industriousness, and of the aspiration of creating a new, un-alienated, humanity, are integrated into a portrait of everyday life in post-war Luanda. As this article will explore, the symbolic development of the film's characters and key tropes affect an understated yet clearly identifiable hermeneutic duality in the film. The film's blend of character-focused drama 
with elements of a social realist aesthetic allows it to offer an up-beat tale of its protagonists' triumph over the post-conflict hardships that the film documents. At the same time, the film can be read as an encrypted allegory, presenting a more pessimistic assessment of endemic alienation and corruption as ills perpetuated by the logic of neoliberal economics and the broken promises and unaccountability of government and national institutions, that can be remedied only by a return to a socially inclusive developmental agenda. This strategy of symbolic encryption, essential to the film's articulation of protest in circumstances of informal censorship, itself possesses a distinguished nationalist and revolutionary pedigree, having been employed across lusophone Africa and Portugal in what are now canonical literary and cinematic works associated with the struggle against the colonial Estado Novo (New State). The Hero's reuse of this strategy in its examination of present-day injustices suggests the continuing relevance of a socialist concept of popular national culture, and of political and aesthetic principles associated with 'Third Cinema', in an early twenty-first century African state recovering from decades of violence and destruction.

\section{Constructing Angola for a global audience: The Angolan everyman between social realism and docudrama}

When interviewed about The Hero, Zézé Gamboa has stressed his intention of 'contributing directly to the task of national reconstruction', and of deploying cinema as a 'powerful medium for development' in a region where illiteracy rates remain high (Gamboa, cited in Africavenir International [2010] and Ruigrok [2004]). ${ }^{5}$ To as great an extent as anywhere in Africa, however, Angolan film-makers must secure both funding and production amenities from outside their own country, as well as distribution on the international film festival circuit, before they can hope to reach a broad local audience. Thus, it seems as much by necessity as by choice that the film was conceived as 'a universal story' that would resonate in 'Central Europe, Latin America, Africa and in all the places where there is or there was war [...] showing children - the former instruments of war - that it is possible to live in peace' (Gamboa, cited in Africavenir International [2010]). The requisite financial and technical support was secured in Portugal and, particularly, in France, Gamboa having worked in both countries for much of the 1980s 
and 1990s, after resigning his post at the Angolan state television corporation in 1980 (Kehr 2005). The film was well-received critically, scooping the 2005 Sundance Film Festival Jury Prize for World Cinema and more than 25 other film festival awards to date, and achieved modest box-office success on general release in Portugal (May 2004) and France (December 2005). ${ }^{6}$ Its subsequent release in DVD format (both by California Newsreel in the United States, and by Bosque Secreto in Portugal and worldwide) facilitated its circulation (most often in pirated editions) in Angola, where by 2004 only a handful of cinemas survived, screening films in $35 \mathrm{~mm}$ and Betacam formats. ${ }^{7}$ The concern to simultaneously engage and inform both the film festival circuit and local audiences translates into a focus on local specificities that are easily grasped by foreign audiences, and an approach to camerawork and editing that draws on the conventions both of social realism and of more contemporary and more bankable aesthetics of (allegedly) documentary drama. ${ }^{8}$ This approach permits a balance between an emotionally engaging personal story and a deft outline of a cross-section of society in Luanda, towards the culmination of the 2002-2003 demilitarization process. The film clearly illustrates how the infrastructure and environment of this once handsome capital city have been hugely compromised by a largely unmanaged population explosion, as millions of Angolans fled the country's mined and war-torn interior. Most had no option but to scrape a living in the wretched shantytowns or musseques (literally 'sandy places') that now dominate a city whose population mushroomed from around 750,000 in 1975 to an estimated four million by $2000 .^{9}$ Through the post-war programme of demobilization and 'social reintegration', they would be joined by hundreds of thousands of former combatants from the MPLA government military and rebel UNITA army. The lack of water and power supplies, sewerage, or refuse collection, the inadequacy of roads, public transport, and law enforcement, and the paucity of opportunities for education and gainful and legitimate employment suffered by the inhabitants of the musseques is abundantly demonstrated as the film's protagonists are introduced, and is contrasted with the luxury enjoyed by a small coterie surrounding the upper echelons of the MPLA government, and living in opulent gated communities near the city's waterfront. ${ }^{10}$

On the level of plot structure, the film offers a state-of-the-nation analysis by situating its eponymous 'hero' as a post-conflict Everyman, whose journeying around 
Luanda leads him to encounters with a range of social types. Vitório (Oumar Makéna Diop) - whose name indicates the film's use of symbolism and irony to balance a superficial optimism with veiled political critique - is a newly demobbed sergeant who lost a leg to a landmine explosion in the last months of the civil war. At the film's opening, Vitório joins the lucky minority of Angola's estimated 62,500 landmine victims who are provided with a good-quality prosthetic limb. ${ }^{11}$ Although thus once again - in the words of the doctor who supplies his prosthesis - an 'homem válido' (able man), Vitório remains unemployed, homeless, and as thoroughly excluded as many others from the country's spectacular post-war economic boom. ${ }^{12}$ Lacking friends or family for support and sleeping rough on the city streets, he awakens one day to find that his prosthesis has been stolen. In his subsequent struggle to recover it, Vitório crosses paths with four characters whose interventions will help him to achieve the new civilian life that he has so far been denied. The first of these is Maria Bárbara (Maria Ceiça), a mother parted from her family by a UNITA assault, now working under the assumed name of Judite in a Luanda brothel, and searching for her missing son. The second is Manu (Milton Coelho), a bright but troubled teenage orphan, whose introduction to the viewer in the opening credit sequence establishes his story as the film's secondary narrative focus. Growing up amid the squalour of the musseques, and yearning for news of his missing father, Manu is falling inexorably into a life of crime despite the efforts of his grandmother, Flora (Neusa Borges), and of his schoolteacher Joana (Patrícia Bull), the daughter of a well-to-do MPLA activist, who is now disillusioned and struggling to keep faith with her socialist ideals. Vitório meets Joana by chance when he returns to the city hospital seeking assistance after the theft of his leg, and it is she, rather than the hospital staff, who goes out of her way to help him. Exploiting her wealthy playboy boyfriend Pedro's (Raúl Rosário) political connections, Joana arranges for Vitório to make a joint radio broadcast with a government minister (Orlando Sérgio), appealing for Angolan solidarity and for the return of the prosthesis. What none of these latter characters suspect is that the stolen leg is now in the hands of Manu, who swapped a stolen radio for it at one of the notorious scrapyards that are central to Luanda's massive grey-market economy, and is using it in his attempts to contact his father by means of improvised magic rituals. ${ }^{13}$ When, soon after the broadcast, Manu's grandmother discovers the leg, 
she marches Manu to the radio station, where to his shame he recognizes Vitório as the man who had recently saved him from a brutal attack by a local street gang. Nevertheless, all is forgiven; Vitório and Judite/Maria Bárbara - who have, in the interim, fallen in love and resolved to start a new life together - become firm friends with Manu and Flora, and Vitório, through the patronage of the Minister, even gets a job as a government chauffeur.

As the New York Times's critic noted, the film's plot line and its political implications are strikingly similar to Vittorio de Sica's neo-realist classic Ladri di Bicicleta/The Bicycle Thieves (1948). However, while both films use the quest to recover a stolen item to expose the vulnerability of both national reconstruction and of a working man's livelihood to lawlessness, poverty, and the indifference of social and political elites, The Hero foregoes de Sica's indication of a downward spiral into desperation and criminality, in favour of an upbeat conclusion. This neat happy-ever-after ending can make the film look guilty of the charge levelled at a number of recent cinematic engagements with urban poverty and marginalization that have achieved commercial box-office success worldwide. Cidade de Deus/City of God (Fernando Meirelles and Kátia Lund, 2002) and Slumdog Millionaire (Danny Boyle and Loveleen Tandan, 2008) are but the most high-profile cases of depictions of intractable social exclusion, that sugar the bitter sociological pill they deliver with a plot resolution that satisfies audience desires for an inspirational message of (usually individual) triumph over disadvantage. In The Hero, Vitório's exceptional good fortune, and the benefits that trickle down from it to the characters around him, depends largely upon coincidental encounters that prompt the dues ex machina intervention of a powerful benefactor, and also upon the altruism of two women, Joana and Judite/Maria Bárbara, to whom Vitório can initially offer little more than his handsome face and touching life-story. The evocation through these two characters and their plot functions of the most powerful Christian archetypes of female virtue - respectively, the universal mother (Mary) and the redeemed whore (Magdalene) - meanwhile, exemplifies how casting and screenplay decisions allow the film to target audiences in Portugal and Brazil without ignoring Angolan concerns and tastes. Most significant of these is the participation, in leading roles, of the Brazilian telenovela stars Ceiça and Borges. While Gamboa has drawn attention to the difficulties of assembling a wholly local cast in a nation with only four or five active theatre companies (Kehr 2005), 
these actors would not seem the obvious choice for the achievement of a documentary realist aesthetic. Ceiça in particular struggles to modify her Brazilian accent, and moreover maintains the hyperbolically expressive and emotive acting conventions of telenovela in a manner that occasionally jars with the understated performances of Makéna Diop and the Angolan actors. However, the star quality of both women greatly increases the film's visibility and appeal as much in a Brazil that is proudly rediscovering its African roots and cultural ties with Angola, and in an Angola increasingly keen to model itself on the emerging South American powerhouse. Details of the screenplay (cowritten by the film's producer Fernando Vendrell, his wife and fellow Portuguese Carla Baptista, and Frenchman Pierre-Marie Goulet) also appeal to historical and cultural affinities between the lusophone nations. The characterization of Joana, and the references to her Portuguese father's contribution to Angola's independence struggle, highlight the more benign legacies of a 500-year-long colonial relationship (contrasting sharply with the anti-colonialist images that abound in Angola's independence-era cinema). ${ }^{14}$ The implication of a cultural heritage linking Luanda with a wider lusophone community is, meanwhile, also articulated by the focus on shared recreational practices, particularly the beach culture of sun-loungers and seafood restaurants enjoyed by the wealthy and, among the poor, the indulgence in coffee and pastries for women and children, and al fresco beer-drinking for men.

When one sets aside both the audience-pleasing contrivances in The Hero's central plot, and the seductive tokens of cultural familiarity that it offers, however, one is left with images and narrative tropes that function according to dual representational logic to convey a grimmer, and much more politically charged, assessment of the nation's malaise and its prospects for post-war recovery. This dual logic suggests that The Hero's makers' concern with educating a global audience was balanced with a need to secure, from that global audience, the underwriting of the film's projection to the Angolan populace that Gamboa has referred to as his 'público-alvo' or target audience (Gamboa, cited in Spranger [2005]). The film presents Luanda's abject condition in a format that enjoys international audience recognition as possessing (some) documentary credibility, while not being limited by strictly documentary objectives. Embedded within this format, however, is a less universally-recognizable symbolic code that (combined, at a key 
moment, with the discontinuities arising from the casting of Maria Ceiça) destabilizes the film's superficially upbeat ending. This code also serves to suggest an entrenched MPLA kleptocracy's dereliction of any form of national duty, and the inadequacy of the individualist or clientist ethics that justify the country's current reconstruction and development model.

The balance of strategies used to document the systemic economic and social dysfunction of post-conflict Luanda through the exemplary drama of an Everyman 'hero' is clearly outlined in the film's opening credit sequences. The opening image is a travelling aerial shot that scans the Luanda musseques, and shows how they abut the luxury developments housing the MPLA elite. This cuts to a rapid sequence of shots following the action of Manu's gang's basketball game on an improvised open-air court. Together, these images exemplify how the film switches between an infrequent use of social-realist style long shots and ambient soundtrack (suggesting a panoramic perspective and locating protagonists clearly within socio-economic contexts), and a more habitual preponderance of close-ups and point-of-view tracking shots, often accompanied by extradiegetic music, eliciting the viewer's empathy with an individual character's perspective. These two representational approaches are neatly elided in the credits sequence's conclusion, where Manu abandons the game (which, as Angola's most popular professional sport, makes a potent symbol of a boy's aspiration to escape from poverty) and is framed in the panning shot that closes the sequence, taking in a panoramic view of the city centre, the seafront, and the luxury beachside villas of the Ilha de Luanda in the distance. In the subsequent scenes that introduce principal characters and events, each sequence cuts from a brief establishing shot to close-up and point-of-view shots that maintain an alignment with individual experiences while summarizing the nation's woes. The first such sequence presents Vitório's arrival at the overcrowded, under-resourced hospital, where nothing runs transparently or to schedule, where the doctors break their appointments and where, Vitório claims, he has been awaiting the prosthesis promised to him two months earlier while other patients jump the queue. A switch back to Manu then illustrates his slide towards criminality, and hints strongly at the film's intertextual relationship with The Bicycle Thieves, as Manu's gang hone their thieving skills, dismantling a bike chained up on the street and fleeing with the most saleable parts. Flora 
is introduced next, exhausted from work and from carrying water home from distant standpipes through the dangerous musseques, and exasperated by Manu's low motivation for his studies. Manu's inclination to choose a life of crime over education (since, he claims, 'vai dar tudo ao mesmo' [studying makes no difference]) is redoubled when Joana and his other teachers strike in protest at massive arrears in salaries and school budgets. The widespread inaccessibility of basic services like education and healthcare is further demonstrated when power cuts prevent Vitório from reading by the light of the streetlamps, and when there are no buses or even taxis to convey him to hospital. In this situation, Vitório is one of 120,000 newly demobbed combatants who (by the government's estimate) will face unemployment, a phenomenon first introduced as part of Vitório's personal drama (when the foreman of a construction site is sufficiently distressed by Vitório's situation to send him away with some money, since he is unwilling to give building work to an amputee), but then 'documented' in fuller context in a long shot wherein, as Vitório walks towards a huge sign outside a construction site that advises that 'Não há vagas' (there are no vacancies), a luxury SUV glides past him.

The periodic return to a panoramic perspective that this exemplifies allows for the elaboration of characters' psychology to be read (as so often in social realist or neo-realist cinema) as contributing to a representation, in microcosm, of the post-conflict state of the nation. The development of plot lines centred on Vitório or on Manu explores the damage wrought to both individual and collective psychology by decades of conflict. In Vitório's case, the painful and difficult task of coming to terms with an identity forged by experiences of violence, of destruction, and of bereavement that frequently lacks closure is suggested in a shot of him confronting his reflection in the mirror in the hospital gym as he learns how to walk on his new leg. If Vitório is old enough to perceive his country's ruination as an historical process, however, a younger generation is shown to accept lawlessness, theft, and embezzlement as normal. Though Manu is berated by Joana and Flora for stealing, he sees it as his brightest career prospect, and as the means of financing the search for his missing father, and the film charts the progress of his thieving, from bicycle components to luxury items such as a car stereo. Vitório, meanwhile, exemplifies the failures of adults to set a good example. Soon after gaining his prosthesis, he sells his crutches on the grey market rather than returning them to the 
hospital, and uses the proceeds to buy not just basic necessities but also the consolations of fashionable clothing, beer and sex. Moreover, Vitório only secures his prosthesis in the first place by subscribing to Angola's notoriously hierarchical and clientistic social practices, successfully claiming to the hospital doctor his priority, as an army officer and decorated war hero, over injured civilians and military rank-and-file. While pulling rank might be justifiable in order to hold more powerful authorities to account, Vitório later displays real arrogance when he uses his war hero status as justification for jumping the lengthy queue at a water pump. More sinister than this acceptance of larceny, dishonesty and one-upmanship is the widespread desensitization to violence. While casual brutality is inescapable both in the alleyways of the musseques, and in the brothel where Judite/Maria Bárbara works, Manu and his friends demonstrate a fascination with weapons and warfare that betrays their identification of aggression and destructive violence as the most effective solution to their disempowerment. Only after Manu has been attacked and robbed does a shot of him gazing into a bathroom mirror suggest his capacity to reflect on his identity and situation, and on the limited alternatives to violence and crime that are available to him.

While functioning unambiguously to illustrate post-conflict Angolan society's ills, these exemplary scenes constitute a far less clear-cut prescription for national recovery. On the one hand, the film indicates how everyone has suffered through war, acknowledging that violence and trauma damage collective psychology and engender situations in which all parties (not excluding MPLA officers, as Vitório testifies) behave appallingly. Thereby it offers an unthreatening lesson of reconciliation through contrition and forgiveness, without apportioning blame, or venturing near the highly controversial subject of the assimilation into the Angolan government, civil service and military of the UNITA movement and its combatants. ${ }^{15}$ On the other hand, such detail is built around a small group of tropes that, I argue, when read symbolically, articulate the more contentious message that the responsibility of securing Angola's post-conflict recovery lies less with the disenfranchised and alienated Everyman, struggling just to stay alive, than with the MPLA elite, which, through its embrace of neo-liberal economics, and its implication in rampant embezzlement, nepotism and intimidation, has betrayed the 
socialist principles of the era of independence, and reneged on its promises of IDP resettlement, rehabilitation of combatants, elections and de-mining. ${ }^{16}$

\section{Reconstructing national culture for a local agenda: The New Man, labour and progress in post-conflict allegory}

As has been outlined, although Gamboa's aim of documenting the embattled state of the nation and educating a popular audience recalls social realist cinema's aims, The Hero makes more limited recourse to techniques of camerawork, editing and sound montage associated with that movement. At the same time, however, one can identify in the film another inheritance from mid-twentieth century social realist aesthetics, one which is pivotal to the film's representation of the post-conflict nation, and which is, moreover, associated with early affirmations of Angolan independence. This inheritance is the use of symbolic encryption of familiar tropes, prominent within the diegesis, to elaborate upon the film's documentation of everyday life by constructing intersecting and ideologically consistent allegories of socio-economic and political relations. Such encrypted allegory was commonly used in the oppositionist literature and cinema of Portugal and its colonies under the corporatist Estado Novo from the 1940s onwards, serving to articulate polemics that could not, under strict censorship conditions, be presented transparently in representations of national life. A 'neo-realist' aesthetic in fiction, and the supple and extensive lexicon of encryption elaborated by novelists such as Alves Redol, Carlos de Oliveira and, in Angola, Castro Soromenho, became strongly associated with the Marxist-led struggles for independence and for cohesive new national identities across Portuguese-ruled Africa. ${ }^{17}$ It is interesting to speculate on whether the choice of this rhetorical strategy was determined purely by the alarming intimations - in the first years of the new millennium - of intolerance of outspoken public criticism among members of the MPLA elite, or was, as seems eminently plausible, made expressly in order to rehabilitate components of the socialist culture of the pre- and postindependence era and use them as vehicle for the reaffirmation of 'national' values, allegedly betrayed by the Party's neo-liberal turn. ${ }^{18}$

The beginnings of an answer to this question derive from a study of the choice of basic tropes from which The Hero's allegory is built. If some of these activate the stock- 
in-trade images and metaphors of nationalist discourse worldwide - for example, houses and families and the (re)building of both - others relate more specifically to the rhetoric of socialist Angola's national affirmation. Of these latter, the most distinctive and most prominent are the 'hero' Vitório and his broken and reconstructed body. The metaphorical loading of these tropes is the basis for allegories of the vicissitudes of two interlinked national projects of the socialist period, namely, an accelerated industrialization according to socialist principles, and the creation, through education, economic reform, and revolutionary socialization, of a new humanity.

The concept of the Communist 'New Man' originates as an idea briefly sketched in Marx's early essays, first acquiring ideological quiddity in 1920s Bolshevist writings, and widely taken up by post-colonial Marxist movements in the 1960 s and 1970s. ${ }^{19}$ Its development in the political theory and propaganda of the post-independence MPLA drew significantly on the programme outlined in Che Guevara's 1965 essay 'Socialism and Man in Cuba', and on the Cuban programme of education and social mobilization designed to bring forth an un-alienated proletarian subjectivity; that is, a working man loyal to the social collective, and committed to the socialist and emancipatory values of the revolution. ${ }^{20}$ MPLA theorists synthesized this model with theories (not least those of Amílcar Cabral and Frantz Fanon) that addressed the specific challenges faced by revolutionary movements in post-colonial Africa, focussing on the need to 'decolonize' African minds and to effect cohesion across ethnically diverse nations, while also recuperating indigenous traditions, purged of 'regressive' or 'unscientific' elements, for revolutionary national cultures. ${ }^{21}$ As a political project, this New Man's creation is now almost universally confined to history. The concept has however, retained an uncommon degree of prominence in the political and patriotic discourse of Angola. It takes pride of place in the national anthem, 'Angola, avante!' (Forward, Angola!), which asserts that: 'Honramos o passado e a nossa história / Construindo no trabalho o homem novo (We honour the past and our history / Building the New Man through our work), and is a central concept in texts central to the canon of national literature, such as Pepetela's As Aventuras de Ngunga (The Adventures of Ngunga) (1972). ${ }^{22}$

The Hero's Vitório, born roughly five years before independence, and pressganged into the MPLA army aged fifteen, has grown not into the 'New Man' of which 
his parents' generation dreamed, but rather into a war-torn and traumatized subject. In this context, ironic echoes of the independence-era dream of a new humanity in, for example, the doctor's claim that Vitório is about to 'começar uma nova vida' (begin a new life) reinforce the symbolic manipulation of Vitório's body as multiple metaphor for a dysfunctional Everyman or national subject injured and diminished by war, and for a perverted and paralyzed project of national industry and progress, as well as for a damaged and fragmented nation in need of reconstruction that would integrate and harmonize all constituent parts.

The significance of Vitório's body and its reconstruction as central and uniting elements in intersecting allegories of the nation is established in the sequence in which Vitório, newly fitted with his prosthesis, joins dozens of fellow war casualties who are rehabilitating injured or maimed bodies in the hospital gym. Shots of patients rhythmically pulling and pushing the levers and pulleys of rowing machines and weighttraining equipment, and of physiotherapists manipulating limbs like stubborn machinery, are accompanied by a soundtrack of whirring chains, humming motors and metallic bangs and clicks. What is evoked is not simply physical recovery, but also the process, fundamental to the New Man's construction, of the harmonization of the human with a revolutionary, mechanized, and all-inclusive economic order. Vitório's physical reconstruction and rehabilitation is thus developed into a synecdoche of a recommenced national developmental project. At the same time, the notion that the miscarriage of postconflict 'social reintegration' threatens the nation's future is suggested by a variation on the familiar use of the trope of amputation as a metonym of castration (an unsurprising topic, given the organization of the diegesis around two male characters, and the reflection of patriarchal values and anxieties in, for example, the film's construction of women characters and representations of family life). The film modifies the conventional metonym, focusing on the loss of the prosthesis, rather than of Vitório's original leg, as symbolic castration, and thereby avoiding a simplistic analogy between disability and emasculation. ${ }^{23}$ Vitório's symbolic castration by the loss of his prosthesis becomes apparent through the progress of his acquaintance with Manu. The two meet when Vitório intervenes to save Manu from the gang who threaten to kill him, striking the gang leader's knife out of his hand with his crutch and vowing he will kill any of the youths 
who harm 'my son'. Manu's elated response - 'sempre sabia que tu irias voltar, pai' (I always knew that you'd come back, father) - and his subsequent dejection when Vitório confesses that he has lied simply to make his threat more convincing, creates a sense of pathos. This in turn prepares the ground for the plot's touching resolution, in which the characters' destiny of forming a happy family together is signalled when Maria Bárbara, meeting Manu for the first time, declares that 'esse menino podia ser meu filho' (that boy could be my son). However, this creation of a 'prosthetic' family of and for the bereaved and dispossessed cannot get underway when Manu and Vitório first meet: Vitório must depart immediately for the hospital, where he hopes to be fitted with a new prosthesis. Only after the interventions of the minister and Dona Flora impel Manu to return the original can Vitório re-enter his life, accompanied by Maria Bárbara, and take on a paternal role. By means of this phallic metaphor, The Hero suggests the need for Angolan society to acknowledge relations and responsibilities that are as much paternal as fraternal. First the state that Vitório has served all his adult life - and under whose command he was maimed - must belatedly shoulder its responsibilities (as when Vitório tells the doctor who amputated his leg that 'Você tem de ser responsável pelo que fez' (You must take responsibility for what you have done). Thereafter, Vitório can provide the necessary compliment to Flora and Joana in teaching the teenage Manu to shoulder his responsibilities.

The contrast between the universal responsibilities of honesty and solidarity, and the practices that have become habitual in Angolan public life, is of course highlighted by a third and most crucial metaphorical treatment of the trope of the dismembered and reconstructed body. The development of the plot specifically around the theft of an artificial limb affords a factually accurate illustration of the vast trade in stolen goods that keeps Luanda's unofficial economy moving, and of the massive human cost of this trade. At the same time, the leg's theft offers a metaphoric expression of how national reconstruction is confounded, as much by the astronomical scale of larceny towards the apex of the social pyramid as by the petty thieving in the musseques. According to the IMF's calculations, revenue from the state-owned Songangol oil company roughly equivalent to one quarter of national GDP during the late-1990s to mid-2000s is unaccounted for. ${ }^{24}$ Just as for Vitório, his prosthesis (figuratively and literally one quarter 
of his rebuilt body) was 'a minha independência' (my independence), the complement that makes him a 'homem válido' (able man) fit to father an orphan child, so the Angolan nation cannot free itself of dependence on foreign aid, and on the cynical patronage of global powers and globalized capital, while being routinely robbed of such an vital portion of its wealth.

The Hero's political critique appears most incisive, however, when one considers the interplay between these metaphorical treatments of the body, and those of images of houses, machines and labour. Depictions of the reconstruction and repair of houses and vehicles that attest to Vitório's exclusion from gainful employment also ironically recall the status of labour as a site of national pride and unity, and its centrality to the socialist vision of national Bildung, evident in the choice of an engine-cog as central motif of the Angolan flag. In this context, the 'Everyman'’s joblessness - despite his physical strength and mechanic's training - connotes the state's abandonment of industry as a national virtue, and of the aim of liberation through democratic industrialization. As is indicated in a scene where Vitório is refused work on a building site, the privatization of housing and land for residential development excludes the ex-combatant from a purportedly national reconstruction that benefits only the oil-rich elite and foreign investors and speculators. $^{25}$ The film's exploitation of the trope of gates and doorways develops this exposé of how the new realities of housing, property development, and access to state amenities are excluding most of the nation from the post-conflict 'recovery'. A close-up point-of-view shot of the gate to wealthy Dona Palmira's villa being shut on Manu (who has just delivered her order of cakes), powerfully evokes the elitist privatization of urban space. By 2004 thousands of Luanda's musseque dwellings had been forcibly cleared, without compensation or the re-housing of residents, in order for the government to sell land titles for the development of luxury housing. ${ }^{26}$ Meanwhile, the film shows the 'houses' of state institutions and services, such as the hospital, the Ministry building where Pedro works, and the radio station (outside whose gate Vitório must await his benefactor the Minister) as accessible only to those with private transport and/or powerful contacts. Whereas such institutions' assistance to ordinary citizens is at best the minimum necessary, and is usually tainted by the corrupt practices and broken promises of those in authority, it is in the humble homes of Flora, Joana, and Judite/Maria Bárbara that Vitório 
and Manu are afforded protection, nourishment, love, and familial (and thus, synecdochically, national) reintegration. The emphasis on the homes of common people as the true site of national reconstruction and reconciliation is most graphic in the scene near the film's close that unites Vitório, Maria Bárbara, Manu and Flora for lunch as a post-conflict, post-nuclear family. Hand in hand with Maria Bárbara (who has now buried her wartime identification with the Old Testament, righteous courtesan Judith, and reassumed the name of the saint who protects against explosions and sudden deaths), Vitório can mount the steps to the open door of Dona Flora's house without the aid of a stick. Reconstruction, at a popular level, takes place where citizens think as a (patriarchal, socialist) community, trusting, investing in, and actively supporting one another.

The trope whose symbolic treatment most politicizes the film, however, is that of the transport vehicle. On both documentary and allegorical levels, representations of vehicles and of characters' relationships with them powerfully communicate the idea of post-conflict Angola as a two-track nation. Whereas, according to the ideology and symbolism of the independence era, the nation-state is a machine whose parts need to be serviced, and need to work in harmony in order for the whole to move forward, in reality, progress for the greater part of the nation is stalled while the state-controlling elite speeds ahead. While Vitório pleads for work with small-time mechanics labouring on beat-up wrecks, his passage around Luanda is crossed by chauffeur-driven government cars and luxury jeeps. Later, after the theft of his prosthesis, public transport provision is so exiguous that he can reach the hospital only thanks to a ministry chauffeur moonlighting as a candongueiro taxi driver. ${ }^{27}$ The film's numerous shots of burned-out wrecks of buses, trains, and fighter planes assume greater poignancy when ruinous and rusting train carriages form a backdrop to the scenes in which Manu is pursued and violently mugged as he walks through the musseques to deliver cakes to Joana. Together these scenes suggest how the national community is endangered equally by lack of access to public vehicles (which are shown to be indispensable to people's independence and enterprise), and by the progress of the privileged elite in isolated luxury in vehicles that are turned into objects of unhealthy desire and agents of social division. As Pitcher and Graham (2006: 183) argue, the MPLA top command's provision of cars to key middle-ranking 
bureaucrats is a classic tactic of clientist rule, 'designed to avoid the adoption of public solutions to collective problems by buying off potential opponents one by one'.

The socially exclusory consequences of clientistic privatization of transport is most powerfully illustrated in two scenes that together offer a dialectical image of how '[luxury] cars are killing Luanda' (Pitcher and Graham 2003: 173): that in which Pedro knocks down a street child in his jeep while arguing with Joana, and that in which the Minister's car is blocked from exiting the radio station, not by the clamoring journalists who have gathered to question him, but by a silent, staring crowd of landmine victims using crutches and wheelchairs. If Pedro's reluctance to take the injured boy to hospital exemplifies an MPLA bureaucrat's aversion to fulfilling his social responsibilities as a private citizen, the Minister's response to the crowd suggests his barely greater concern for responsibility in his capacity as a leading public servant. After reluctantly pausing to reiterate his promises of aid for the war-wounded and dispossessed, the Minister gets back into his car and grimly tells his driver to 'Anda devagar. Não quero matar ninguém' (Drive on slowly. I don't want anyone to get killed).

These representations of cars as mortal dangers are literally as well as metaphorically apposite in the depiction of a city where "the risk to pedestrians from poor driving and excess speed [...] has become so great that more pedestrians than occupants of cars die in traffic accidents' (Anon. 2005: 18, cited in Pitcher and Graham 2006: 18). However, the latter sequence in particular makes the invitation to a symbolic reading one that sharpens the film's political connotations - almost too obvious to ignore. As the camera cuts to a shot inside the Minister's car, the hubbub of the journalists outside is silenced as the car's automatic windows close: while state bureaucrats' privileges and the privatization of space render critical voices inaudible and ineffectual, high-tech vehicles, far from carrying the nation's new men (and women) forward, cut a path for the elite through a swathe of war-damaged, un-rehabilitated and silently suffering humanity.

\section{Deconstructing happy endings: Cinema as cultural prosthesis in post-conflict Angola}

Returning, after this exploration of The Hero's use of encrypted allegory, to this article's opening questions about the possibility of film-making in Angola that is both 
commercially viable and profitably engaged with local political and cultural concerns, it seems appropriate to recall Paul Willeman's insistence upon a flexible or hybrid aesthetics for Third Cinema, as a 'historically analytic yet culturally specific mode of cinematic discourse' (1989: 3). Just as, according to Willeman, politically-engaged popular cinema must recognize 'the historical variability of the necessary aesthetic strategies to be adopted' (1989: 7), in accordance with the opportunities and restrictions of its circumstances of production and reception (1989: 3), the makers of The Hero recognize that, for their critique of post-conflict Angola to reach Gamboa's popular, local 'target audience', its harshest and most inflammatory elements must be veiled both for a global audience unreceptive to polemic and Afro-pessimism, and for a potentially censorious Angolan governmental elite. Their achievement lies in veiling these elements by means of symbols and aesthetic strategies that possess particular (though not exclusive) local currency, thereby signalling to an Angolan audience their privileged position as recipients of the film and as arbiters of its meanings. Moreover, at the same time as Gamboa and his collaborators offer this 'target audience' privileged insights into political and cultural realities outside itself, they successfully use 'cinematic strategies designed to explore what dominant regimes of signification were unable to deal with' (Willeman 1989: 7) in a manner that also alerts their international audience to the gap between Angolan realities and their representation through what one might term 'feelgood cinema with a social conscience'. This occurs when the film's compromise between documentary and character-led drama breaks down spectacularly in a sequence filmed on the set of the real-life TV initiative Ponto de Re-encontro/Reuniting Point (from early in 2003, a regular slot featured in the Televisão Pública de Angola (TPA) programme Nação Coragem/ Courageous Nation, whose title is a play on the Portuguese term for meeting point, 'ponto de encontro'). One of the most imaginative government initiatives to expedite post-conflict rehabilitation, Reuniting Point has enabled thousands of Angolans to broadcast appeals for news of missing loved ones, and is filmed weekly at a site on Luanda's Praça da Independência where the public can also access registers documenting the status and last known whereabouts of displaced and missing persons. ${ }^{28}$ With the permission of its makers and participants, Gamboa shot footage of the programme in production, incorporating it into his film as a backdrop to Maria Bárbara's 
search for her son. In the sound editing of an initial sequence depicting real-life displaced persons queueing to receive, and to appeal for, information, Gamboa overlaps the voices of programme participants recording their messages, and deploys a cumulative echo effect that builds to an uncanny, low-pitch hubbub, effectively denoting the incomprehensible scale of the human tragedy that Reuniting Point addresses. The sequence thereupon homes in on cinema's inevitable failure as representation of the reality of that tragedy, through a sequence of apparently real-time takes of the programme's (real-life) participants, queuing to present their appeals to camera, that concludes with a (fictional, acted) appeal made by Maria Bárbara. Throughout this sequence, Maria Ceiça is visually anomalous, being considerably taller and paler-skinned than any of the Angolan women alongside her; what thoroughly shatters the scene's reality effect, however, is her Brazilian accent and her hyperbolically physical and emotive delivery, which concludes in grimaces of misery and wracking sobs. The disjunction between what the viewer knows to be a paid telenovela actor's performance, and the undemonstrative delivery of those identifiable as Reuniting Point's real-life contributors, challenge the viewer to acknowledge the gulf between the daily experience of actual trauma and bereavement, and the occasional experience of its representation, in historical drama or in documentary, as melodrama or tragedy for essentially voyeuristic consumption.

Paradoxically, yet perhaps inevitably, The Hero's success as a contribution towards a politically-engaged Angolan popular cinema derives from the visibility of its representational failures and ambiguities, and its compromises with more powerful political and cultural agendas. After these have been advertized, in the sequences just discussed, it becomes easier to identify how, in the film's closing sequence, the allegorical structures established earlier destabilize the optimistic message seemingly implicit in the plot's conclusion. Manu pays his adoptive father a visit in his new job as ministry chauffeur, and Vitório takes him for a ride along the Luanda waterfront in the minister's car. An allegorical reading of the scene would suggest that both are finally inside the functioning part of society and making progress, yet questions remain. The success stories that have led them there remain exceptions to the rule, the car is not theirs, and indeed borrowing it (and the fuel in its tank) is arguably an act of theft from the 
nation. Will the protagonists' new quasi-familial relationships be consolidated? Have Manu and Vitório really learned their respective lessons about 'Angolan solidarity', or have they been co-opted into the hegemonic system of patronage? Where is the car qua national project heading, and will it pick up any more passengers? And finally, one might add, what influence might the dissemination of cultural products with didactic intention amongst Angola's dispossessed citizens have in terms of healing the nation's postconflict ills?

A tentative answer to this last question emerges if one entertains the possibility of a more recondite metaphoric treatment of Vitório's rebuilt body, one that compounds the troubling implications of an allegorical reading of the closing sequence. Comparing the relationship of Vitório and his artificial leg to that of the Angolan nation and contemporary cinema will sound less quixotic if one accepts the concept of '[popular] national culture as a mediating prosthesis that enables a people's self-return through selfincarnation and recognition in the external world' that Pheng Cheah identifies as 'central to most theories of African literature' (Cheah 2003: 358), but as most effectively elaborated by the Kenyan novelist and cultural theorist Ngũgĩ wa Thiong'o. ${ }^{29}$ Ngũgĩ's characterization of culture as prosthesis is situated within his organicist conception of the post-colonial nation developing 'according to its inner biological processes and its interactions with external surroundings' (Cheah 2003: 354). Prostheses - as foreign bodies impinging upon the nation's organic whole - are instrumental in such interaction, and can 'supplement a deficiency and provide essential support if [...] properly attached and utilized' (2003: 352). The bad prosthesis, however, does not become part of the organic body but 'acts as a conduit [...] [that] opens the body to external forces and even makes it dependent on them' (352). The globally dominant force of finance capital, Cheah summarizes, 'reproduces neocolonial relations in post-colonial spaces by attaching various prostheses onto the popular-national organism' (352). For Ngũgĩ, the deadliest of such prostheses is the clientist state, which in the case of Angola could be characterized as heir to the colonial era Creole comprador elite, a state that governs to maintain the economic abjection and political inertia of the population while siphoning off the country's mineral wealth (or as Cheah puts it, reducing the nation to 'spare parts for the global capitalist machine' [355]). In this situation, Ngũgĩ has argued, the state and other 
neocolonizing prostheses can be 'dissolved' by the deployment of culture as 'a more salutary prosthesis' (352) of the living national body that 'presses against the state in order to inspirit it and transfigure the degraded present' (12). Indeed,

\begin{abstract}
Popular national culture is the paradigmatic example of a good prosthesis for two mutually reinforcing reasons: It originates from the people. But more importantly, through collective psychical incorporation, it also plays a crucial role in the nation's continuing self-formation. (Cheah 2003: 356)
\end{abstract}

Cheah's review of Ngũgĩ's theory of culture as prosthesis concludes by using Derrida's exploration of spectrality, and concept of hauntology, to interrogate whether or not 'culture possesses the self-recursive organismic causality that makes it the bearer of freedom' (352). Reading The Hero's depiction of Vitório's relationship to his prosthesis as allusion to the concept of culture as redemptive prosthesis, meanwhile, highlights a simpler, but equally fundamental, problem. Just as Vitório's potentially redemptive prosthetic leg is provided by foreign donors under the auspices of the 'neocolonial' state, in Angola today the cinematic projection of a vision originating 'from the people' is contingent on negotiation with sponsoring institutions partially or wholly aligned with a neocolonizing agenda, and thereby liable to alienate that vision from its popular origins. In the future, the proliferation of low-budget digital imaging and editing technology may provide outlets for a popular-national screen culture (such as are unlikely to arise from the current revival of state-owned film and TV production in Angola). While any future Angolan revolution will most probably not be televised, popular campaigns for justice may find mobile phone cameras and YouTube to be indispensable, if unreliable, tools of mobilization and education (as recent developments in Mozambique, Kenya, and across the Arabian peninsula and North Africa suggest). ${ }^{30}$ In the meantime, while in The Hero's political allegory, Vitório may end up using his prosthesis to depress the accelerator pedal of the state-owned machine, the viewer cannot be certain whether the leg has come to represent an integral part of the organic body of the nation, or whether, conversely, it is the symbolic agent of Vitório's incorporation into the clientist and kleptocratic body of the state, which props up the hegemony of global capitalism. ${ }^{31}$ It remains to be seen whether or not a recuperated national ethos - represented by the war-torn New Man, the 
valorization of industry over capital and the concept of 'Angolan solidarity' - will 'inspirit' the state, or whether the state will infiltrate the national body and corrupt its agency. Just as the Angolan population has, with stoicism and ingenuity, refashioned the abandoned hardware and blighted environment of decades of war into viable utilities, commodities and habitats, so too the rhetorical and symbolic artillery of an independence-era popular liberation project, wrecked by cold war hostilities and by exclusory economic restructuring, can be recycled in the production of cultural artifacts that speak to post-conflict realities. For as long, however, as the tools of such cultural production are restricted to those loaned by, or shared with, unsympathetic or neocolonizing forces, such artifacts cannot be guaranteed to transmit a vision of liberation, or any pre-supposedly redemptive popular-national ethos.

\section{References}

Abrantes, Mena (1987), 'Cinema Angolano: Um Passado a Merecer Melhor Presente/ Angola Cinema: A Past Deserving of a Better Present', in Anon. (ed.), Cinema Angolano, Lisbon: Cinemateca Portuguesa, pp. 13-31.

Accessed 12 September 2011.

Africavenir International (2010), 'African Perspectives: “O Heroi” by Zeze Gamboa' [sic.], 29 May, Studio 77, Windhoek, Namibia, http://www.africavenir.org/index.php?id=32\&tx_ttnews\%5Btt_news\%5D=131207\&cHas $\underline{\mathrm{h}=1313 \mathrm{ee} 5 \mathrm{db} 357 \mathrm{c} 1 \mathrm{c} 9 \mathrm{e} 8 \mathrm{e} 5 \mathrm{a} 9 \mathrm{ef7e} 4 \mathrm{e} 736 \mathrm{f}}$. Accessed 18 October 2010.

Amnesty International (2007), 'Angola: Lives in Ruins: Forced Evictions Continue', 15 January, http://www.amnesty.org/en/library/info/AFR12/001/2007. Accessed 14 November 2010.

Anon (2005), 'Motorista assassina pequeno de doze anos/ Motorist kills 12-year-old', Folha 8, 14 May, p. 8.

Anon (2010a), 'Angola: Poverty level nearly halved in a decade', Les Afriques: The African Finance Journal, http://www.lesafriques.com/en/international/angola-povertylevel-nearly-halved-in-a-decade.html?Itemid=35? articleid=0330. Accessed 22 October 2010. 
Anon (2010b), 'O Grande Kilapy de Zézé Gamboa', Rua de Baixo, 60, September 2010, http://www.ruadebaixo.com/o-grande-kilapy-de-zeze-gamboa.html. Accessed 18 October 2010.

Araújo, Nelly Cristina de Oliveira (2005), “UM SÓ POVO, UMA SÓ NAÇÃO”: O discurso do Estado para a construção do homem novo em Angola (1975-1979)/ ONE PEOPLE, ONE NATION: State discourse towards the construction of the New Man in Angola', Masters thesis, Universidade de São Paulo.

Arenas, Fernando (2010), Lusophone Africa: Beyond Independence, Minneapolis:

University of Minnesota Press.

Birmingham, David (2002), 'Angola', in Patrick Chabal (ed.), A History of Postcolonial Lusophone Africa, London: Hurst, pp. 137-84.

Boyle, Danny and Tandan, Loveleen (2008), Slumdog Millionaire, UK: Celador Films/Film4/Pathé.

Chabal, Patrick and Vidal, Nuno (2007b), 'Social Neglect and the Emergence of Civil Society', in Patrick Chabal and Nuno Vidal (eds.), Angola: The Weight of History, London: Hurst, pp. 200-35.

Cheah, Pheng (2003), Spectral Nationality: Passages of Freedom from Kant to

Postcolonial Literatures of Liberation, New York: Columbia University Press.

Ferreira, Ana Paula (1992), Alves Redol e o Neo-Realismo Português/Alves Redol and Portuguese Neo-Realism, Lisboa: Caminho.

Fortunato, Orlando (2004), O comboio da Canhoca/The Canhoca Train, Angola/France: Unifrance.

Gamboa, Zézé (2004), O Herói/The Hero, Angola/France/Portugal: David \& Golias/Gamboa \& Gamboa/Les films de l'aprés-midi.

Ganga, Maria João (2004), Na Cidade Vazia/Hollow City, Angola/Portugal: Animatógrafo II/ Integrada.

Global Witness (2004), 'Time for Transparency: Coming Clean on Oil, Mining and Gas Revenues', http://www.globalwitness.org/sites/default/files/pdfs/oil_061.04.04.pdf. Accessed 14 November 2010. 
Guevara, Ernesto 'Che' (1969 [1965]), 'Socialism and Man in Cuba', in Rolando E. Bonachea and Nelson P. Valdés (eds. and trans.), Che: Selected Works of Ernesto Guevara, Cambridge, MA and London: The MIT Press, pp. 155-61.

Hodges, Tony (2003), Angola: From Afro-Stalinism to Petro-Dollar Capitalism, Bloomington: Indiana University Press.

Hodges, Tony (2007), 'The Economic Foundations of the Patrimonial State', in Patrick Chabal and Nuno Vidal (eds.), Angola: The Weight of History, London: Hurst, pp. 175-99.

http://www.angonoticias.com/full_headlines.php?id=4093. Accesssed 18 October 2010. Human Rights Watch (2003), 'Struggling through Peace: Return and Resettlement in Angola', http://www.peacewomen.org/portal_resources_resource.php?id=677. Accessed 14 November 2010.

Human Rights Watch (2004a), 'Some Transparency, No Accountability: The Use of Oil Revenue in Angola and its Impact on Human Rights', http://www.hrw.org/node/12196. Accessed 14 November 2010.

Human Rights Watch (2004b), 'Unfinished Democracy: Media and Political Freedom in Angola', http://www.hrw.org/en/node/77703. Accessed 14 November 2010.

Human Rights Watch (2009), 'Democracy or Monopoly? Angola's Reluctant Return to Elections', http://www.hrw.org/en/node/80926/section/8. Accessed 14 November 2010. Human Rights Watch/SOS Habitat (2007), “"They Pushed Down the Houses": Forced Evictions and Insecure Land Tenure for Luanda's Urban Poor', http://hrw.org/reports/2007/angola0507/angola0507web.pdf. Accessed 14 November 2010.

International Committee of the Red Cross (2003), 'Angola - ICRC Tracing Activities: One year on', http://www.icrc.org/eng/assets/files/other/angola_mai_03.pdf. Accessed 17 November 2011.

Internet Movie Database (n.d.), 'The Hero', http://www.imdb.com/title/tt0424142/. Kehr, Dave (2005), 'Part Tale, Part Real: Film from Stricken Angola', New York Times, 24 March, http://www.nytimes.com/2005/03/24/movies/24hero.html?_r=1. Accessed 18 October 2010. 
Landmine and Cluster Munition Monitor, (2007), 'Angola: Country Report', http://www.the-monitor.org/index.php/publications/display?url=lm/2007/angola.html. Accessed 18 October 2010.

Marx, Karl (1961), Economic and Philosophical Manuscripts of 1844 (ed. and trans. T. B. Bottomore), New York: Frederick Ungar.

Meirelles, Fernando and Lund, Kátia (2002), Cidade de Deus/City of God, Brazil/France: O2 Filmes/VideoFilmes/Globo Filmes/Lumiére/Wild Bunch.

Méssiant, Christine (2007), 'The Mutation of Hegemonic Domination', in Patrick Chabal and Nuno Vidal (eds.), Angola: The Weight of History, London: Hurst, pp. 93-123. Moorman, Marissa (2001), 'Of Westerns, Women, and War: Re-situating Angolan Cinema and the Nation', Research in African Literatures, 32: 3, pp.103-22. Ngũgĩ wa Thiong'o (1993), Moving the Centre: The Struggle for Cultural Freedoms, Portsmouth, NH: Heinemann.

Ngũgĩ wa Thiong'o (1998), Penpoints, Gunpoints, and Dreams: Towards a Critical Theory of the Arts and the State in Africa, Oxford: Clarendon.

Paget, Derek (1998), 'Codes and Conventions', No other way to tell it: Dramadoc/ Docudrama on television, Manchester-New York: Manchester University Press, pp. 61-89.

Péclard, Didier (2008), 'Les Chemins de la "Reconversion Autoritaire" en Angola/ The Routes of 'Authoritarian Reconstruction' in Angola', in Didier Péclard (ed.), Politique Africaine, 110, 'L'Angola dans la paix: Autoritarisme et reconversions/ Angola in Peacetime: Authoritarianism and Reconstruction', pp. 5-20.

Pires, José Cardoso (1972), ‘Changing a Nation's Way of Thinking', Index on Censorship 1: 1, pp. 93-106.

Pitcher, M. A. and Graham, A. (2006), 'Cars are killing Luanda: Cronyism, consumerism and other assaults on Angola's postwar capital city', in M. J. Murray and R. A. Meyers (eds.), Cities in Contemporary Africa, New York: Palgrave Macmillan, pp. 173-94. Rius, Hugo (1976), “"Construiremos un hombre nuevo, angolano y universal”/ "We will build a new man, Angolan and universal", interview with António Jacinto, Verde Olivo, 17: 3, 18 January, pp. 19-21. 
Ruigrok, Inge (2004), 'Angolan Cinema Flourishes after the War: Interview with Zézé Gamboa', De Kracht van Kultuur, http://www.powerofculture.nl/uk/specials/cinema_in_africa/angola.html. Accessed 18 October 2010.

Sabine, Mark (2011), 'Re-fitting the Lexicon of Resistance: Saramago, symbolism and dictatorship', in Alison Ribeiro de Meneses (ed.), Legacies of War and Dictatorship in Contemporary Spain and Portugal, Oxford-Bern: Peter Lang.

Scruton, Roger (1982), 'New Man', A Dictionary of Political Thought, London: Macmillan, p. 322.

Sica, Vittorio de (1948), Ladri di Biciclette/The Bicycle Thief, Italy: Produzione de Sica. Spranger, Paulo (2005), “'Como Angola está, eu não podia fazer um filme alegre”: Zézé Gamboa/ "The way Angola is today, I could not make a cheerful film”: Zézé Gamboa', Diário de Notícias/ Daily News, 15 February,

TV Brasil (2010), 'O instinto de sobrevivência da TV Angolana/ Angolan TV's survival instinct', http://www.tvbrasil.org.br/novidades/?p=6230. Accessed 14 November 2010. União Nacional de Artistas Plásticos (UNAP) (1979), 'União Nacional de Artistas Plásticos - UNAP: Proclamação/ Announcement: National Union of Plastic Artists (UNAP)', África: literatura, arte e cultura/ Africa: Literature, art and culture, 1: 2, pp. $183-84$.

UNICEF (2010), Information by Country: Angola, http://www.unicef.org/infobycountry/angola_statistics.html\#69. Accessed 22 October 2010.

United Nations (2010), Country Profile: Angola, http://data.un.org/CountryProfile.aspx?crName=ANGOLA. Accessed 14 November 2010.

Vidal, Nuno (2007), 'The Angolan Regime and the Move to Multi-Party Politics', in Chabal Patrick and Vidal Nuno (eds.), Angola: The Weight of History, London: Hurst, pp. $124-74$.

Vines, Alex, and Oruitemeka, Bereni (2008), 'Bullets to Ballots: The Reintegration of UNITA in Angola', Conflict, Security and Development, 8: 2, pp. 241-63. 
Wheeler, Douglas L., and Pélissier, René (2009), História de Angola, trans. by Pedro G. Serras Pereira and Paula Almeida, Lisboa: Tinta da China.

Willeman, Paul (1989), 'The Third Cinema Question: Notes and Reflections', in Jim

Pines and Paul Willemen (eds.), Questions of Third Cinema, London: BFI.

\section{Acknowledgments}

I would like to thank the following colleagues for their invaluable help and advice with the preparation of this article: Fernando Arenas, Roger Bromley, Bernard McGuirk, Paulo de Medeiros, Raquel Ribeiro, and Anthony Soares. I would also like to acknowledge the generosity of the University of Nottingham and of the Arts and Humanities Research Council of Great Britain and Northern Ireland, in making possible the period of research leave during which early drafts of this article were prepared.

\section{Contributor details}

Mark Sabine is Lecturer in Lusophone Studies at the University of Nottingham. He has published extensively on the literatures and visual cultures of nineteenth and twentiethcentury Portugal and lusophone Africa, and in particular on the work of Fernando Pessoa and José Saramago and on post-colonial identities and cultural relations in lusophone communities. His current projects include a forthcoming book on the novels of José Saramago, and the coordination of an international research network on 'Cinema of PostConflict in Africa'.

Contact: University Park, Nottingham, Nottinghamshire, NG7 2RD, UK. E-mail: mark.sabine@nottingham.ac.uk

\section{Notes}

\footnotetext{
${ }^{1}$ As Arenas summarizes, 'Angolan cinema practically disappeared in the 1990s as a result of the civil war and lack of attention from the national government' (2010: 114). See also Moorman (2001: 116) and Abrantes (1987) on the impact on Angolan film production of wartime disruption and budget constraints. ${ }^{2}$ See Vidal (2007) and Arenas (2010: 114-15). On Angola's post-war boom, see Hodges (2007).

${ }^{3}$ See Arenas (2010: 149), and Spranger (2005).

${ }_{5}^{4}$ See Méssiant (2007: 95-98) and Hodges (2003).

${ }^{5}$ Basic literacy in Portuguese among adults in present-day Angola is estimated at 67 per cent (UNICEF 2010).

${ }^{6}$ See also the Internet Movie Database's list of the film's festival screenings up to 2007. The press kit circulated by the film's producers lists 22 awards worldwide; Anon (2010b) updates this to more than 25. I am deeply grateful to Monica Mota, of David \& Goliás production company, for supplying me with a copy of the film's press kit.

${ }^{7}$ The film was screened at the Ciné Atlântico, Luanda, in September 2005, attracting 1348 spectators. Two further screenings took place in Luanda, followed by several regional showings, for which audience figures are not recorded. I am deeply grateful to Monica Mota, of David \& Goliás production company, for supplying this information. Reliable data regarding the film's DVD-format circulation in Angola is
} 
currently lacking. Regarding cinema-going in Angola, Moorman (2001: 119) summarizes that 'Luanda's dilapidated cinemas inhabited by the war's displaced, a former cinema where the parliament now convenes, and theaters converted into high class restaurants are ironic symbols of the contemporary state of the nation in Angola'.

${ }^{8}$ With significant exceptions that will be discussed below, the filming and editing of The Hero conforms to the characterization that Derek Paget offers of 'modern practice in [realist] television drama', with a use of "realist sets or actual locations, "key lighting", sound recorded for maximum clarity of narrative flow, continuity editing $[\ldots]$ and non-diegetic music dubbed in during post-production to influence mood' (Paget 1998: 75).

${ }^{9}$ The precise rate of population growth in Luanda is difficult to ascertain, as no census has been conducted since the 1970s. Pitcher and Graham give figures of 300,000 in the 1950s; 800,000 in the 1970s, and 3.5 million in 2004 (2006: 177, 178). The current UN estimate is 4 million.

${ }^{10}$ In 2006, nearly 40 per cent of urban populations in Angola lacked access to improved water facilities, and over 20 per cent lacked access to improved sanitation (UNICEF 2010). The under-five year mortality rate was 220 births per thousand in 2008, dropping from 260 at the height of the war in 1990. Life expectancy nationally stood at 47 years in 2008, rising from 42 in 1990. Pitcher and Graham estimate that the 'core' of the wealthy elite, funded by state oil revenues in a manner that guarantees MPLA power as a form of 'pacted autocracy', numbers around 3,000 individuals, though there are also 'layers and layers of beneficiaries' of a clientistic relationship with the top of the government hierarchy (2006: 177).

${ }^{11}$ On Angola's landmine crisis, and the provision of health care for landmine detonation survivors, see the Landmine and Cluster Munition Monitor report (2010).

${ }^{12}$ Most sources concur in reporting that, in 2002, around 65 per cent of Angola's population lived below the UN-recognized poverty level of US $\$ 1.25$ per day. Recent government claims that the poverty has been reduced to c.38 per cent were endorsed by UN observers (see Anon. 2010), but are disputed by many other parties.

${ }^{13}$ On the trade in stolen commodities in Luanda, see Pitcher and Graham (2006: 186).

${ }^{14}$ Moorman (2001: 112-15) offers a thorough overview of Angolan film production, 'targeted for local audiences' and aiming 'to record the political and military activities and the celebrations of independence' (2001: 112) between 1975 and the early 1980s. The critique of Portuguese colonial violence and exploitation is notably acute in the documentary series Sou Angolano, Trabalho com ForçalI am Angolan, I Work Hard (various directors, 1975-1976); in Ruy Duarte de Carvalho's series of shorts Angola 76 - É a vez da voz do Povo/Angola 76 - It's Time for the Voice of the People (1976), and in Carlos, Víctor and Francisco Henriques's documentary Viva o 4 de Fevreiro/Long Live the 4th of February (1977).

${ }^{15}$ See Méssiant (2007: 104-07, 111-13), and Vidal (2007: 138-43, 150-57).

${ }^{16}$ The parliamentary elections promised by President dos Santos in 2002 were finally held in September 2008, with MPLA candidates winning an overwhelming majority (see Wheeler and Pélissier [2009: 375] and Human Rights Watch [2009]). After many years of postponement of presidential elections, in early 2010 the Angolan parliament revised the national constitution, so as to establish the leader of the party with the largest number of parliamentary seats as president.

${ }^{17}$ On symbolic encryption in 'neo-realist' and oppositionist writing in Portugal and its colonies, see Ferreira (1992), Cardoso Pires (1972) and Sabine (2010).

${ }^{18}$ On allegedly politically-motivated killings of journalists and NGO activists in Luanda, see Birmingham (2002: 183) and Human Rights Watch (2004b).

${ }^{19}$ See Marx (1961) and Scruton (1982). My sincere thanks go to Robert Chilcote for bringing these sources to my attention.

${ }^{20}$ See Guevara (1969 [1965]), Araújo (2005), Rius (1976) and UNAP (1979). My sincere thanks go to Tony Kapcia, Christabelle Peters, Kelly de Oliveira Araújo, Betty Rodríguez-Feo, and Delinda Collier for their generosity in advising me regarding this Cuban-Angolan debate, and for providing me with access to many of these texts.

${ }^{21}$ See Araújo (2005). I am indebted to António Tomás for his summary, posted on the H-Net Lusophone Studies Discussion List on 22 October 2010, of Cabral's influence as 'the African leader who pushed this idea further, through the dialectics of the liberation zones'.

${ }^{22}$ In assessing the continuing currency of the 'New Man' concept in Angola and the wider lusophone world, one should note that the other internationally successful Angolan film of 2004, Ganga's Hollow City uses the device of schoolchildren's staging of an adaptation of Pepetela's novel to draw a stark comparison 
between the young Ngunga's formation as a revolutionary and patriot, and the neglect and exploitation of the film's child protagonist, N'dala (João Roldan), in 1990s Luanda.

${ }^{23}$ It should be noted that Vitório's reiteration of his doctor's pronouncement that he is an 'homem válido' (able man), and his lament that 'o meu prótese foi a minha liberdade' (my prosthesis was my freedom), emphasize the situational, rather than essential, nature of his disability.

${ }^{24}$ Chabal and Vidal (2007: 229, note 9) notes the IMF's calculation of state revenues equivalent to 23 per cent of national GDP being unaccounted for in the period 1997-2001. On allegations of corruption and embezzlement within the civil service, see also Hodges (2007: 187-90), Human Rights Watch (2004a) and Global Witness (2004).

${ }^{25}$ While the film provides the example of the Portuguese property developer, in reality the most significant investors have been Chinese companies who generally have sent their own skilled workers to staff Angolan operations rather than maximizing job opportunities for locals.

${ }^{26}$ On forced evictions and demolitions in the Luanda musseques, see Amnesty International (2007), and Human Rights Watch/SOS Habitat (2007).

${ }^{27}$ On public transport and taxi services in Luanda, see Pitcher and Graham (2006: 182).

${ }^{28}$ For accounts of Reuniting Point and its impact, see International Committee of the Red Cross (2003) and TV Brasil (2010).

${ }^{29}$ Cheah here refers principally to arguments presented in Ngũgĩ wa Thiong’o (1993; 1998).

${ }^{30}$ I refer here to use of mobile phones, phone cameras, and social networking sites in the mobilization and documentation of the protests of the 2011 'Arab Spring' in Egypt, Syria, Bahrain and elsewhere, as well as in the organization of protests against planned rises in food prices in Mozambique in August 2010, and in gathering evidence of violence and other crimes committed following the disputed outcome of the Kenyan presidential elections of 2008.

${ }^{31}$ As Cheah (2003) encapsulates Ngũgĩ's argument in Moving the Centre, 'Like a pilot in a machine, genuine culture directs the national body's interaction with economic and political forces so that it can finally return home to itself from externality' $(356-57)$. 